Ethiopian Journal of Environmental Studies \& Management 8(5): 593 - 605, 2015.

ISSN:1998-0507

doi: http://dx.doi.org/10.4314/ejesm.v8i5.12

Submitted: March 26, 2015

Accepted: July 22, 2015

\title{
SOCIO-ECONOMIC CHARACTERISTICS OF URBAN RESIDENTS AND INTRA-URBAN TRIP GENERATION: AN ILLUSTRATION FROM ABEOKUTA, OGUN STATE, NIGERIA
}

\section{SOLANKE, M.O.}

Department of Geography and Regional Planning, OlabisiOnabanjo University, P.M.B 2002, Ago-Iwoye, Nigeria

Email: solankeolayiwola@yahoo.com

\begin{abstract}
The developed and emerging urban centres of today generate and attract complex trip pattern because of their multifarious functions. However, concentration of trip generation studies on developed urban centres in Nigeria creates the need for such exercise in the emerging cities. This study thus, focused on socio-economic characteristics of urban residents and their influences on intra-urban trip generation in Abeokuta, an intermediate urban centre in Nigeria. Data on twelve socio-economic characteristics of residents and trip generation pattern were collected from 429 households in the chosen urban centre. Simple bivariate correlation and multiple regression techniques were used to process data generated. Six socio-economic characteristics of residents significantly account for $53.80 \%$ ( $F$ $=82.001, p \leq 0.01)$ of variation in the criterion. In order of importance, the variables and their level of contribution are: Number of workers $37.70 \%(t=16.074, p \leq 0.01)$, age $6.90 \%,(t=$ 7.294, $p \leq 0.01)$, rent 4.90\% ( $t=6.429, p \leq 0.01)$, occupation $2.60 \%(t=4.758, p \leq 0.01)$, length of stay $0.80 \%(t=2.693, p \leq 0.01)$ and income $0.90 \%(t=2.933, p \leq 0.01)$. Emerging/intermediate urban centres in Nigeria have similar pattern as major centres in terms of trip generation and this deserves adequate attention to avoid the crisis experienced in the major urban centres in the future.
\end{abstract}

Key Words: Trip generation, Urbancentres, Socio-economic variables, Intra-Urban travel, Trip determinants, Nigeria

\section{Introduction}

Human movements made possible by transportation are fundamentals in the creation, development and growth of cities. Hence, the pivotal role of transport in overall development and well-being of society cannot be overemphasized.

The urban centre of today is complex in nature, covers large expanse of land and accommodates varied activities (Aderamo, 2004; Solanke. 2005; Osoba, 2011 and Raji, 2013). It is the centre of administrative, industrial, commercial, educational, social and recreational activities.

An outcome of these developments is that the various landuse components of urban centre are separated, one from the other. Most people now live in one part of the city and work, shop or recreate in other parts. Also, children school in other parts, while places of worship as well as the residences of friends and relatives are still in other parts. Now, long distances are 
involved in intra-urban movements. The mode of movement for intra-urban travel which was characterized by trekking in early period had been replaced by mechanical locomotion such as bicycles, motorcycles, motor cars, buses etc.

It then becomes necessary for interaction to increase within the urban centre. Hence, urban centre of today generates and attracts very large number of person trips daily and because of its multifarious function, urban centre is complex in the pattern of its interaction and traffic. Consequent upon trip generation and attraction, many urban centres are now witnessing what can be described as a period of relative immobility. Immobility not in the context of the complete absence of traffic on the urban roads, but immobility arising from delay, slow and chaotic transportation in urban centres. This situation calls for attention on trip generation study, if commuting is to improve in our various urban centres.

Intra-urban travel represents an expression of an individual's behavior and as such it has the characteristics of being habitual. As a habit, it tends to be repetitive and the repetition occurs in definite pattern (Brutton, 1975). Studies (Ayeni 1974, Ogunsanya 2002, Solanke 2005; Osoba 2011, Raji 2013) have shown that in general, people tend to travel to a variety of other peoples' services and facilities that are not available at the Origins of their journeys.In addition, evidences abound from previous urban travel studies supporting association between intra-urban trip generation and socio-economic characteristics of urban residents.

However, while urban transportation, consequent upon trip generation is attaining crisis dimension in virtually every urban centre in varying degrees previous studies to resolve the crisis concentrate on major cities like Lagos metropolis and Ibadan.
Many other urban centres in the country today are showing signs of potential bottlenecks in their transportation system. There is therefore the need to conduct studies on trip generation in these emerging/intermediate urban centres to provide insight to transportation planning and avoid the chaotic situation of Lagos type in the future. To this end, this study focuses on Abeokuta, an ancient but growing urban centre in an attempt to examine the significance of socio-economic status of residents on urban trip generation. In other words, while the influence of socio-economic characteristics of people in urban travels are fairly well known in most developed urban centres, the phenomenon is yet to be established for emerging urban centre. Attempt is therefore made in this study to extend the trip generation studies in major urban centres to the emerging/intermediate cities of Nigeria. This is with a view to identify the important socio-economic characteristics of households in emerging urban centres that influence trips generated.

Study Area

The Study Area, Abeokuta is the capital of Ogun state, Nigeria (see figure $1)$. The city is located on Latitude $7^{\circ} 15^{\prime}$ north and Longitude $3^{\circ} 25^{\prime}$ east (see figure 2 ). It is a nodal urban centre situated about 81 kilometers south-west of Ibadan, the capital of Oyo state, 106 kilometres north of Lagos, the former capital of Nigeria, 63 kilometers from Ota; the growing industrial centre.

\section{Economic Activities}

In terms of economic activities, Abeokuta is fast growing as a result of the presence of local resources, rapid population growth and enhanced political status (Oyesiku and Kojeku, 1992). There are numerous identifiable modern economic activities in the city including banks, insurance houses, modern and traditional markets, petrol stations motor 
companies, and commercial enterprises. There are few large-scale industrial establishments while medium and small scale plants engaged in saw milling, food processing, clothing, woodworks, carving, quarrying, pottery, dyeing confectionery and steel works are numerous in the town. Furthermore, thousands of the residents engaged in paid employment of the local, state and federal government agencies in the city. Others engaged in business activities which are dominated by distributive trade, personal services, finance and insurance services.

\section{Population}

Abeokuta remains the largest city in Ogun state in terms of population. It is a growing primate urban centre and is developing rapidly. The rapid increase in the population of residents of the town has been essentially due to natural increase, immigration and rural-urban drift.

The city had a population of 84,451 in 1952 which increased to 187,292 in 1963. By 1976, when the town became the capital of Ogun state, the population rose to 258,183 . Since then, the increase has been more rapid. The provisional figure for the 1991 census exercise by national Population Commission put the figure at 374,843 . This increased to 566,973 in 2006 , 643,878 in $2010,664,353$ in $2011,685,479$ in 2012 and 707,277 in 2013. This rapid population growth, coupled with the buoyant economic activities suggest a great demand for trip generation in the city.

\section{Transport Infrastructures}

The transport network in Abeokuta can be described as essentially that of a single mode: The Road. Other mode is the railway that traversing the western end of the town. There are no river port and airport. Lagos North rail line that began in 1898 passed through Abeokuta via Ifo in 1900. By this development as the case in Nigeria generally, the rail preceded road in terms of modern wheeled transport development in Abeokuta.

In the recent time landmark remarkable improvements had been made in intra-city routes in order to give the town a befitting outlook as a state capital. Apart from tarring all the roads, overhead bridges are provided at strategic locations and major highways within the town are developed to multiple lanes to ease traffic flows.

The major modes of road transportation in the town are private cars and taxis. Buses, unlicensed private vehicles used for passengers' transport popularly known as 'Kabukabu' as well as motorcycle are also operating. Thus, private operators dominate intra-city passenger transport services in Abeokuta.

\section{Social Amenities}

Abeokuta has over 250 free and feepaying nursery and primary schools, over 100 secondary (Junior and Senior combined) schools, 1 technical College, 1 Federal College of Education, 1 Polytechnic, 1 Private University and a Federal University of Agriculture. It also has 2 Federal government Health Institutions, 8 state government hospitals/Health Centres and Dental Clinics, over 50 private/mission hospitals and over 30 private maternity homes. Being the state capital and fast growing urban centre, Abeokuta has attracted both government and private individuals' attention to invest in outdoor recreational facilities. These include stadia and hotels; for instance there are well over 60 standard hotels, motels and guest houses in Abeokuta.

The socio-economic characteristics of the state no doubt reveal its complex nature. All these socio-economic activities as earlier noted are potentials for trip generation. Thus, a study on trip generation towards efficient transport system within the city cannot be overemphasized. 
Socio-Economic Characteristics of Urban Residents and Intra-urban Trip Generation.................SOLANKE

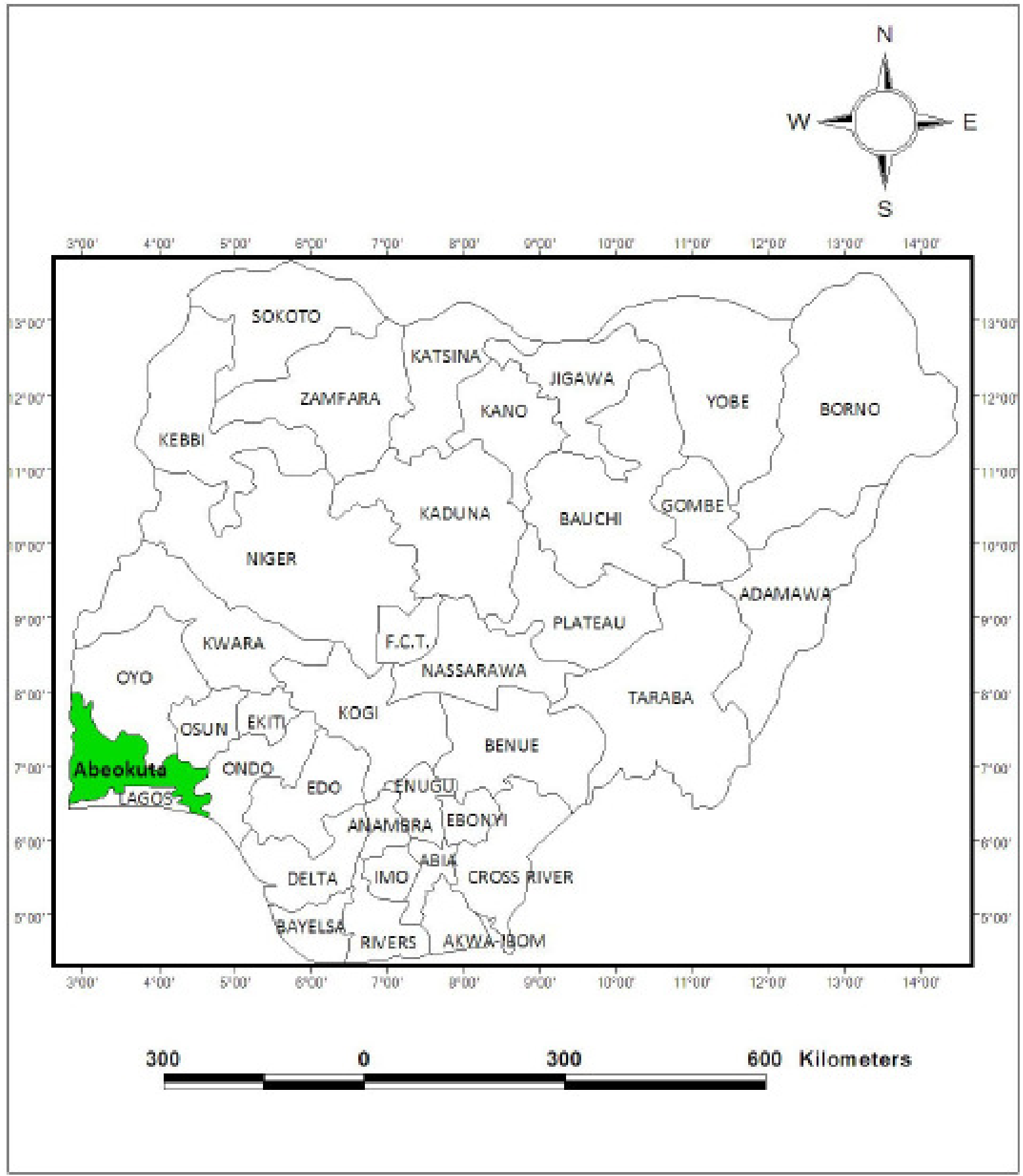

Figure 1: Map of Nigeria showing study area Abeokuta 
Ethiopian Journal of Environmental Studies and Management Vol. 8 no. 5, 2015
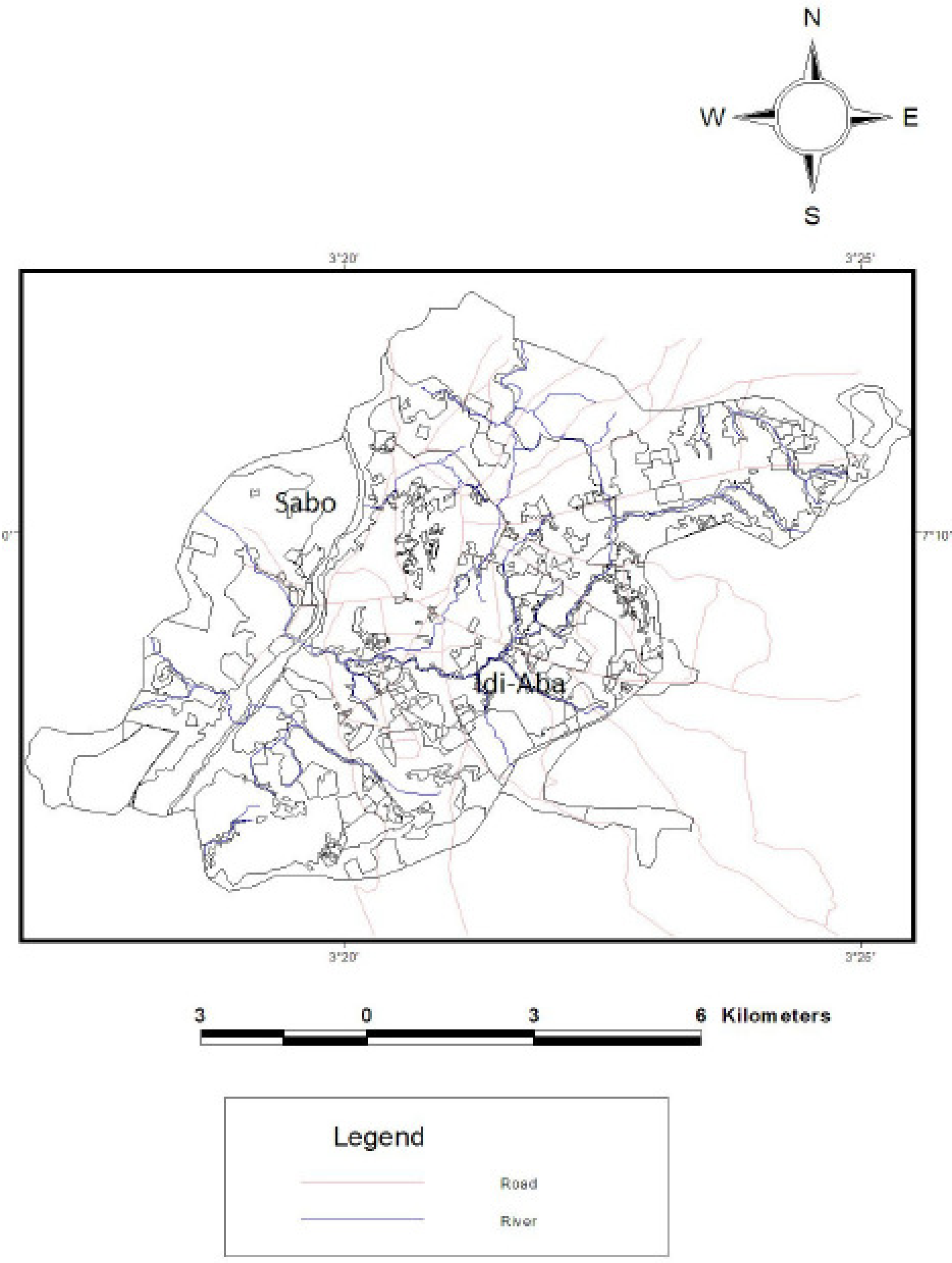

Figure 2: Map of Abeokuta

\section{Method}

Sources of Data

The data for this study were collected through questionnaire survey. The survey covers urban residents on household basis. Following the works of Ogunjumo (1986), Oyesiku (1990), Solanke (2005, 2006) household is a well known key decision 
making unit for the general movement pattern and constitutes the major point of origin of urban travel. The questionnaire deals with information on socio-economic characteristics and trip generation by urban residents.

Following the works of Ayeni (1974), Ogunjumo (1986), Olayemi (1977), Oyesiku (1990), Solanke (2005, 2006), Osoba (2011) among others, multiple item indices are used to measure socio-economic status of the respondents. These include: sex, age, marital status, educational level, occupation, occupation category, monthly income and automobile/vehicle ownership. Other important measures considered as potentials of household trip generation in this study are: length of stay, number of workers,mode of travel and estimated annual rent paid. The annual rent paid is considered here as another measure of economic power aside income as previous studies have shown that in survey research, respondents often inflate income for ego boosting or deflate them for tax evasion.

In all, twelve socio-economic characteristics of households are considered important measures of travel behavioural pattern and determinants of trip generation. Urban residents were requested to construct their trips within the past one week to date of survey. The immediate past week to date of survey was chosen in order to collected information from them while they are still fresh in their memory, thus enhance the accuracy of the information.

\section{Sampling Techniques and Questionnaire Administration}

For the purpose of questionnaire administration, the urban centre was divided into residential quarters along the demarcation of the town into residential neighbourhoods by the Town Planning Authority.
In each of the neighbourhoods, the number of streets was identified and a random selection made. On each street, systematic random sampling technique was employed to select each housing unit in which the target respondents reside.

The size of the household sampled was based on the estimated 2013 population for the urban centre. This was about 707,277 people. It was assumed that the average household size in the study area was about five (Solanke, 2005). Based on this assumption, there were 141,455 households in the study area as at the time of survey. Out of these, 500 households were randomly selected across the neighbourhoods.429 households (86\%) fully completed their questionnaires and constitute the data base for this study.

\section{Technique of Analysis}

The simple bivariate correlation and multiple regression analysis were employed to process the data generated. The simple bivariate correlation was used to examine interrelationships among the variables on one hand and the relationship between each of socio-economic variables and trips generated on the other hand.

The contribution of each of the socioeconomic variables to the trips generated was established through multiple regression. The multiple regression is of the form:

$$
Y=a_{0}+b_{1 \times 1}+b_{2 \times 2}+\ldots b_{n x n}+e
$$

Where:

$\mathrm{Y}=$ the criterion or dependent variable (volume of household trips per week)

$\mathrm{a}=$ the intercept of the regression plane

bi $=$ regression co-efficient

$\mathrm{xi}=$ the predictor or explanatory or independent variables (socio-economic variables)

$\mathrm{e}=$ stochastic disturbance or error term 
The twelve explanatory variables were regressed against the criterion. (Volume of household trips).

The stepwise version of the model was used because it derives the best regression equation from a set of explanatory parameters in a step-by-step version. The explanatory variables are considered one after the other on the basis of their partial correlation with the criterion (dependent variable). The independent variable which exhibits the highest partial correlation with the criterion variable is considered first in the regression equation while the one with the greatest proportion of the residual variance is considered next.

At every stage of the analysis, a significant test is carried out using ' $\mathrm{f}$ ' and t' statistics to ascertain the reliability of the variance contributed by any newly entered independent variable in the overall relationship.

An aspect of regression model also employed in this study is the use of dummy variables. A dummy variable is an index, which is constructed with considerable arbitrariness but in a way relevant to the influence of the factor concerned (Kontsoyiannis, 1973).

Dummy variables are used for data in binary or dichotomous form rather than interval or ratio scale as required by multiple regression technique. It is a process that increases the application of the regression model and does not cause its estimates to lose any of its properties (Lewis-Beek, 1980; Solanke, 2005).

Examples of such variables in binary or dichotomous form in this study are: sex, marital status, occupation, occupation category, education level, auto-ownership, and mode of travel.Such variables were mutually and exclusively calibrated by assigning nominal values of 0 and 1 . Other variables that were measured on interval or ratio scale were coded by assigning the raw continuous figures provided by households.

The calibrations of the explanatory variables are presented in table 1 . Incorporation of dummy variables into regression analysis has been favoured in research. Examples include Oyesiku (1990), Okoko (2000) and Solanke (2005).

Table 1: Calibrations of explanatory variables of Urban Travels

\begin{tabular}{|c|c|c|}
\hline Variable Definition & Variable Label & Calibrations \\
\hline Sex & Resex & Female $=0$ Male $=1$ \\
\hline Age & Reage & Coding is continuous $(20,30-70)$ \\
\hline Marital status & Rems & Single 0 otherwise 1 \\
\hline Occupation & Reoccup & Schooling, Retiree, Unemployed $=0$ otherwise $=1$ \\
\hline Occupational category & Reoccupc & $\begin{array}{l}\text { Farming/Agriculture, Industry/Manufacturing } \\
\text { Commerce/Trading, construction }=0, \text { otherwise }=1\end{array}$ \\
\hline Education level & Reedu & Below secondary education $=0$ otherwise $=1$ \\
\hline Length of stay & Relostay & Coding is continuous $(1,2,3 \ldots \mathrm{n})$ \\
\hline Monthly Income & Reincome & Coding is continuous ( ...) \\
\hline Rent & Rent & Coding is continuous ( $\mathrm{v} \ldots$... \\
\hline Auto-ownership & Re autown & No $=0$ otherwise $=1$ \\
\hline Mode of Travel & Remorav & Public Transport $=0$, otherwise $=1$ \\
\hline No of workers & Noworker & Coding is Continuous $(1,2,3 \ldots 7)$ \\
\hline $\begin{array}{l}\text { No of Trip generated } \\
\text { (Dependent Variable) }\end{array}$ & Totrip & Coding is continuous (Trips per week $-10,20,30 \ldots$ ) \\
\hline
\end{tabular}


An attempt is also made to examine the traditional multicollinearity problems amongst interrelated independent variables. Following the works of Oyesiku (1990, 1995),Solanke (2005) and Raji (2013), the Hauser (1974) measure (i.e. correlation coefficient of 0.80 and above) is used to check for multicollinearity problem.

\section{Results and Discussions}

The correlation coefficients between the socio-economic characteristics of the respondents are shown in table 2. There are generally low correlation coefficients between the variables, although some variables have fairly high coefficients. For instance, for income and auto-ownership the coefficient is 0.404 , income and mode of travel (0.487) and number of workers and sex (0.397) among others. The highest correlation coefficient of 0.822 is between auto-ownership and mode of travel. Since this is the only case of a very high relationship between variables, it is assumed, there is no serious problem of multi-collinearity, among the variables that could substantially affect the results of the multiple regression analysis.

Table 2 also reveals that nine out of twelve explanatory variables have significant positive relationships with trips generated by households. These are: Number of Workers $(\mathrm{r}=0.614, \mathrm{P} \leq 0.01)$ Age $(\mathrm{r}=0.465, \mathrm{P} \leq 0.01)$, Marital Status $(\mathrm{r}$ $=0.429 \mathrm{P} \leq 0.01)$, Rent $(\mathrm{r}=0.396, \mathrm{P} \leq$ $0.01)$, Income $(r=0.346, P \leq 0.01)$, Sex $(r$ $=0.342, \mathrm{P} \leq 0.01)$, Auto-ownership $(\mathrm{r}=$ $0.331, \mathrm{P} \leq 0.01)$, Mode of travel $(\mathrm{r}=0.78$, $\mathrm{P} \leq 0.01)$ and length of stay $(\mathrm{r}=260, \mathrm{P} \leq$ 0.01). These suggest that substantial proportion of the explanatory variables is potential factors of trip generation in the study area.

The results of regression analysis are presented in table 3. Six significant predictors emerged among the socioeconomic variables and they account for $53.8 \%(\mathrm{~F}=82.001 \mathrm{P} \leq 0.01)$ of the variation in the criterion. In order of importance and significance number of workers contributed $37.70 \%(\mathrm{t}=16.074 \mathrm{P}$ $\leq 0.01)$ followed by age $(6.90 \%, t=7.294$, $\mathrm{p} \leq 0.01)$ rent $(4.90 \%, \mathrm{t}=6.429, \mathrm{p} \leq 0.01)$ and occupation $(2.60 \%, \mathrm{t}=4.758, \mathrm{p} \leq$ $0.01)$. Length of stay with $0.80 \%(\mathrm{t}=2.693$ $\mathrm{p} \leq 0.01)$ and income with $0.90 \%(\mathrm{t}=2.933$ $\mathrm{p} \leq 0.01)$ contributed very lowly to the criterion.

More than any other variables the number of workers in household contributes significantly and overwhelmingly to the household trip generation. This can be explained by the fact that the higher the number of gainfully employed people in a household, the higher the propensity to generate multifarious trips. Each worker in a household for instance has domestic, official, communal and societal obligations to meet, all of which culminate in increased household trips.

The finding of this study, particularly for income variable deserves some comments. Ordinarily, one expects some high positive and significant contribution from income in view of economic nature of travel activities. This result is however not too disturbing when one considers that the significant and more powerful variables like number of workers and rent are surrogates or indicators of income. The low contribution of income variable can therefore be explained by the tendencies of individuals to either inflate incomes for ego boosting or deflate them for tax evasion. Suffice to say that researchers need to be critical in using income as a singular measure of economic well being of households in developing nations for these obvious reasons. 
Table 2: Intercorrelations between socio-economic characteristics and trip generated

\begin{tabular}{|c|c|c|c|c|c|c|c|c|c|c|c|c|c|}
\hline & Resex & Reage & Reedu & Reoccup & Reoccupc & Rems & Reincome & Relostay & Reautown & Remotrav & Noworker & Rent & Totrip \\
\hline Resex & 1 & .082 & $.169 * *$ & .033 & -.041 & $.237 * *$ & $.371 * *$ & 0.57 & $.326 * *$ & $.265^{* *}$ & $.397 * *$ & $.257 * *$ & $.342 * *$ \\
\hline Reage & & 1 & -.081 & .009 & .031 & $.374 * *$ & .086 & $.344 * *$ & $.206^{* *}$ & .084 & $.357 * *$ & $.158 * *$ & $.465 * *$ \\
\hline Reedu & & & 1 & .071 & .050 & $-.117 *$ & $.279 * *$ & $-.203 * *$ & $.161 * *$ & $.228 * *$ & $-.124 *$ & $.342 * *$ & .026 \\
\hline Reoccup & & & & 1 & -.090 & $-.274 * *$ & $.105^{*}$ & .014 & $.098^{*}$ & .061 & $.300 * *$ & $.138 * *$ & .020 \\
\hline Reoccupc & & & & & 1 & $-.206 * *$ & -.070 & $-.104 *$ & $-.106 *$ & $-.140 * *$ & $-.150 * *$ & -.014 & -.058 \\
\hline Rems & & & & & & 1 & $.280 * *$ & $.344 * *$ & $.284 * *$ & $.235 * *$ & $.513 * *$ & $.230 * *$ & $.429 * *$ \\
\hline Reincome & & & & & & & 1 & $-.100 *$ & $.404 * *$ & $.487 * *$ & $.381 * *$ & $.313 * *$ & $.346 * *$ \\
\hline Relostay & & & & & & & & 1 & $.133 * *$ & .011 & $.158 * *$ & .053 & $.260 *$ \\
\hline Reautown & & & & & & & & & 1 & $.822 * *$ & $.261 * *$ & $.496 * *$ & $.331 * *$ \\
\hline Remotrav & & & & & & & & & & 1 & $.219 * *$ & $.495 * *$ & $.278 * *$ \\
\hline Noworker & & & & & & & & & & & 1 & $.270 * *$ & $.614 * *$ \\
\hline Rent & & & & & & & & & & & & 1 & $.396 * *$ \\
\hline Totrip & & & & & & & & & & & & & 1 \\
\hline
\end{tabular}

** Correlation is significant at the 0.01 Level.

* Correlation is significant at the 0.05 Level. 
Table 3: Summary of Multiple Regression Results: Socio-Economic Characteristics and Intra-City Trips Generated

\begin{tabular}{|c|c|c|c|c|c|c|c|c|}
\hline Variables & $\begin{array}{l}\text { b } \\
\text { Coefficient }\end{array}$ & $\begin{array}{l}\text { STD Error } \\
\text { of } b \\
\text { Coefficient }\end{array}$ & Multiple R & $\begin{array}{l}\text { Level of } \\
\text { Explanation } \\
\% \\
\end{array}$ & $\begin{array}{l}\text { Cumulative } \\
\text { Level of } \\
\text { Explanation \% }\end{array}$ & $\begin{array}{l}\text { F Value of the } \\
\text { Equation }\end{array}$ & $\begin{array}{l}\text { Beta for } \\
\text { Variables }\end{array}$ & $\begin{array}{l}\text { T Value for } \\
\text { Variables }\end{array}$ \\
\hline No worker & 8.795 & 0.547 & 0.614 & 37.70 & 37.70 & $258.360 * *$ & 0.614 & $16.074 * *$ \\
\hline Age & 6.883 & 0.944 & 0.668 & 6.90 & 44.60 & $171.574 * *$ & 0.282 & $7.294 * *$ \\
\hline Rent & 0.144 & 0.022 & 0.704 & 4.90 & 49.50 & $138.986 * *$ & 0.231 & $6.429 * *$ \\
\hline Occupation & -7.537 & 1.584 & 0.722 & 2.60 & 52.10 & $115.205 * *$ & -0.169 & $4.758 * *$ \\
\hline Length of stay & 2.345 & 0.871 & 0.727 & 0.80 & 52.90 & $94.974 * *$ & 0.096 & $2.693 * *$ \\
\hline Income & 2.708 & 0.923 & 0.734 & 0.90 & 53.80 & $82.001 * *$ & 0.110 & $2.933 * *$ \\
\hline Sex & 1.600 & 1.132 & 0.735 & 0.20 & 54.00 & $70.738 * *$ & 0.054 & 1.414 \\
\hline Marital Status & 1.816 & 1.436 & 0.736 & 0.20 & 54.20 & $62.184 * *$ & 0.054 & 1.265 \\
\hline Education & 1.133 & 1.057 & 0.737 & 0.10 & 54.30 & $55.422 * *$ & 0.042 & 1.072 \\
\hline $\begin{array}{l}\text { Occupation } \\
\text { category }\end{array}$ & 0.523 & 0.934 & 0.737 & 0.10 & 54.40 & $49.830 * *$ & 0.019 & 0.560 \\
\hline Auto. Ownership & 0.925 & 1.026 & 0.737 & 0.00 & 54.40 & $45.208 * *$ & 0.012 & 0.288 \\
\hline Mode of Travel & -0.252 & 1.624 & 0.738 & 0.00 & 54.40 & $41.345^{* *}$ & -0.010 & 0.155 \\
\hline
\end{tabular}

$\begin{array}{ll}\text { No of Cases: } & 429 \\ \text { Constant: } & 13.337\end{array}$
** Significant at the 0.01 Level STD: Standard

* Significant at the 0.05 Level 
In the light of the results of this study, the emerging regression model for the household trip generation in the study area is as follows:

$\mathrm{HTP}=13.337+8.795 \mathrm{NWK}+6.883 \mathrm{AG}+$ $0.144 \mathrm{RT}-7.537$ OCCP + 2.345LST + 2.708 INC

Where:

HTP = Household Trip, NWK = No of Worker, $\mathrm{AG}=$ Age, $\mathrm{RT}=$ Rent, $\mathrm{OCCP}=$ Occupation, LST $=$ Length of stay, INC = Income

The positive regression coefficients in the model imply that the higher these variables, the more the trips generated. However, the negative co-efficient of occupation variable shows that households headed by people who are fully or partially employed generate more trips than their counterparts headed by students, retirees or unemployed.

The emerging model of household trip generation in the study area shows that, in intermediate urban centres in Nigeria, social and economic status of residents have influence on their trip generation. In other words, the socio-economic characteristics of residents can encourage or impose constraints on intra-urban trip generation.

This finding supports the work of Bruton (1975) in London, Ayeni (1974) in Jos, Nigeria, Olayemi (1974), Osoba (2011), and Raji (2013) in Lagos, Nigeria. Thus, the existing knowledge on socioeconomic characteristics of residents and intra-urban trip generation in the developed nation and major cities in Nigeria is applicable in Abeokuta (an intermediate and emerging city), Ogun state, Nigeria. It must however be emphasized that the significant socio-economic variables may not be the same in major and emerging urban centres. For instance, number of workers, age and rent play dominant roles in this study, whereas the previous studies in major cities reveal greater influence of income, auto-ownership among others.

\section{Summary and Conclusion}

This study is on the influence of socioeconomic characteristics of urban residents in intra-urban trip generation with a focus on Abeokuta, an intermediate urban centre in south western Nigeria.

The data for the study were sourced from questionnaire survey of urban residents on household's basis. Twelve measures of socio-economic characteristics of the respondents were employed as indicators of status of residents. These are: sex, age, marital status, education level, occupation, occupation category, monthly income and automobile/vehicle ownership. Others are length of stay, number of workers, mode of travel and estimated annual rent paid. The trip generation was measured through household trips for various purposes on different days for a whole week:

The simple bivariate correlation was used to examine relationships between socio-economic variables and trips generated, while multiple regression analysis was used to examine contributions of predictors to the criterion.

Nine socio-economic variables have significant relationships with trips generated. These are number of workers, age, marital status, rent, income, sex, autoownership, mode of travel and length of stay. Six predictors significantly account for $53.80 \%$ of the variation in the criterion. These are: number of workers $(37.70 \%)$, age $(6.90 \%)$, rent $(4.60 \%)$, occupation $(2.60 \%)$, length of stay $(0.80 \%)$ and income $(0.90 \%)$. Number of workers plays domineering role, followed by age, rent and occupation. Length of stay and income contribute lowly to the criterion. 
Generally, the socio-economic characteristics of residents account for over $50 \%$ of the variation in household trip generation in intermediate cities of Nigeria. Thus, as the case for major urban centres, trip generation in emerging and intermediate cities in Nigeria is to a considerable extent a function of socioeconomic characteristics of the residents.

It is however important to note that although socio-economic characteristics influence trip generation in both major and emerging cities of the country, the significant variables may not be the same in the two categories of urban centre. In this study, number of workers, age and rent play dominant roles whereas the earlier studies reveal prominence of income, autoownership among others. This suggests likelihood of dominance of obligatory trips in the emerging urban centres and a combination of both obligatory and discretionary trips in the developed cities. This constitutes a potential ground for further study in urban trip generation.

\section{References}

Aderamo, A.J. (2004). 'Planning for Urban Transportation in Nigeria' in VanduChikolo I; Ogunsanya, A.A. and Sumaila, A. G. (eds) Perspectives on Urban Transportation in Nigeria, NIIT, Zaria, pp. 312-331.

Ayeni, M.A.O. (1974). "Predictive Modelling of Urban Spatial structure: the example of Jos, Benu-Plateau state, Unpublished Ph.D Thesis, University of Ibadan.

Bruton, M. (1975). Introduction to Transportation Planning Hutchinson, London.

Hauser, D.P. (1974). "Some Problems in the use of step-wise Regression Techniques in Geographical
Research" Canadian Geographer

XVII pp. 148-158.

Kontsoyiannis, A. (1973). "Theory of Econometrics: Introductory Exposition of Econometric Methods. Macmillian Press, London.

Lewis-Beck, M.S. (1980). Applied Regression: An Introduction, Sage University Paper Series on Quantitative Application to Social Sciences, sage publications, Beverly Hills.

Ogunjumo, A. (1986). "The Pattern of trip generation at Ile-Ife" Journal of Nigerian Institute of Town Planners VI and VII, 99-144.

Ogunsanya, A.A. (2002). "Maker and Breaker of Cities" The $59^{\text {th }}$ Inaugural Lecture, University of Ilorin, Ilorin, Nigeria.

Okoko, E. (2000). Quantitative Techniques in Urban Analysis, Kraft Books limited, Nigeria.

Olayemi, D.A. (1977). "Intra-City Person Travel in Metropolitan Lagos: Study of Commuting in a fast growing capital of a developing country" Geoforum, 8: 19-27.

Osoba, S.B. (2011) "Variation in the Ownership of Global System for Mobile Communication (GSM) among socio-economic groups in Lagos, Nigeria" Journal of Logistics and Transport, 3(1): 79-94.

Oyesiku, O.O. (1990). "Inter-Urban Travel Patterns in Nigeria: A Case Study of Ogun State" Unpublished Ph.D Thesis, University of Benin, Nigeria.

Oyesiku, O.O. (1995) An analysis of Demand for Inter-City state in Nigeria. Journal of Transport Studies, 1(1): 17-28.

Oyesiku, O.O. and Kojeku, G.O. (1992). 'Abeokuta' in Onakomaiya, S.O., Oyesiku, O.O. and Jegede. F.J. (ed) 
Ogun State in Maps, Rex Charles Publication, Ibadan pp. 153-156.

Raji, B.A. (2013). Spatial analysis of pedestrian traffic in Ikeja, Lagos state Nigeria, Unpublished Ph.D Thesis, University of Ibadan.

Solanke, M.O. (2005). 'Spatial Analysis of Intra-Urban Travel Patterns in Ogun state, Nigeria' Unpublished Ph.D. Thesis, University of Ibadan, Ibadan, Nigeria.
Solanke, M.O. (2006). 'Analysis of IntraUrban Trip, Generation Patterns in Ogun State, Nigeria Ijagun. Journal of Social and Management Sciences, 1(2): 74-82.

Solanke, M.O. (2013). 'Urbanization, IntraUrban Transportation and the Inherent Challenges in Ogun state, Nigeria. Journal of Logistics and Transport, 5(1): 98-107. 